\title{
Abundance and potential impact of granivorous birds on irrigated rice cultivation, Itajaí, Santa Catarina, Brazil
}

\author{
Abundância e potencial impacto das aves granívoras no cultivo de arroz em \\ Itajaí, Santa Catarina, Brasil
}

\author{
Joaquim Olinto Branco', Bruna Rafaela Keske', Edison Barbieri²*

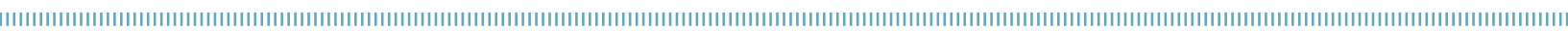

\begin{abstract}
The assemblage of granivorous birds in the irrigated paddy-fields was evaluated over an annual cultivation cycle by means of 12 monthly samplings undertaken in each of 3 areas (of a total of 90 ha) in Itajaí, Santa Catarina, between August 2010 and July 2011. Of a total of 10 species, distributed among 5 families and 2 orders, Sturnella superciliaris (43.88\%) and Sicalis flaveola (36.88\%) were the most abundant. The regular species contributed with $45.17 \%$, followed by the occasional (30.37\%) and the seasonal (24.43\%). Only the abundance of $S$. flaveola presented significant differences between the months of sampling $\left(\mathrm{F}_{11-33}=7.1290, \mathrm{p}<0.01\right)$ as a result of the lower values recorded in December and January. The diversity and evenness indices showed similar fluctuation, with mean values ranging between $0.47 \pm 1.37$ and $0.29 \pm 0.83$, respectively. The average losses per hectare, due to the action of $S$. superciliaris and $S$. flaveola, were $8.35 \pm 1.66$ and $6.10 \pm 1.48 \mathrm{~kg}$ of rice, equivalent to $\mathrm{R} \$ 49.07$ in the 3 areas monitored, giving a total average annual loss of $82.9 \mathrm{~kg}$ for the 90 ha of rice monitored.
\end{abstract}

KEYWORDS: granivorous birds; Sturnella superciliaris; Sicalis flaveola; irrigated rice.
RESUMO: A assembleia de aves granívoras no cultivo de arroz irrigado foi avaliada ao longo de um ciclo anual da cultura, por meio de 12 amostragens realizadas em 3 áreas (90 ha) no município de Itajaí, Santa Catarina, entre agosto de 2010 e julho de 2011. Foram registradas 10 espécies, distribuídas em 5 famílias e 2 ordens, sendo a Sturnella superciliaris $(43,88 \%)$ e a Sicalis flaveola $(36,88 \%)$ as que participaram com as maiores abundâncias. As espécies regulares contribuíram com 45,17\%, seguidas das ocasionais (30,37\%) e sazonais $(24,43 \%)$. Apenas a abundância de $S$. flaveola foi significativamente diferente entre os meses de amostragens $\left(\mathrm{F}_{11-33}=7,1290 ; \mathrm{p}<0,01\right)$, influenciada pelos menores valores entre dezembro e janeiro, enquanto os índices de diversidade e equitabilidade apresentaram a mesma tendência de flutuação, com valores médios oscilando entre $0,47 \pm 1,37$ e 0,29 $\pm 0,83$ respectivamente. O prejuízo médio por hectare, estimado pela ação de $S$. superciliaris e $S$. flaveola, foi de 8,35 $\pm 1,66$ e 6,10 $\pm 1,48 \mathrm{~kg}$ de arroz, equivalente a $\mathrm{R} \$ 49,07$ nas 3 áreas monitoradas, obtendo-se uma média anual de perda de $82,9 \mathrm{~kg}$ em 90 ha de cultivo de arroz estudados.

PALAVRAS-CHAVE: aves granívoras; Sturnella superciliaris; Sicalis flaveola; arroz irrigado. 


\section{INTRODUCTION}

Brazil, with its 1,801 species, holds the third position in diversity of birds, distributed in the most various feeding guilds, to which total 132 species of grain-eaters contribute with about 7.0\% (CBRO, 2014).

Granivorous birds are generally found in dry fields and agricultural areas where they turn the soil in search of grains and seeds. The extensive cultivation of rice, soy and corn attracts large numbers of birds, which cause considerable damage to agriculture (JACINTO et al., 2007; ElPHICK, 2010). However, on removing the husks of these grains, the bird fauna may be poisoned by the insecticides commonly used when treated seeds are planted (Sick, 2001, PARsons et al., 2010).

Rice is the second largest cereal crop in the world, being cultivated on all the continents (FAO, 2010). Brazil is in the ninth position in the world ranking (FAO, 2010), with about 3 million hectares dedicated to this crop and with a total production of 13.61 million tons at the 2010/2011 harvest (CONAB, 2011). Rio Grande do Sul is the greatest national producer, accounting for $66.0 \%$ of the production, followed by Santa Catarina, with $7.5 \%$, cultivated almost exclusively under irrigation (Ministério da Agricultura, 2010).

The cultivation of rice under the system of irrigation represents an ecosystem with seasonal humid areas of foreseeable and dynamic structure, favoring the development of complex and mature communities (DiAs; Burguer, 2005; SANDILYAN et al., 2010). Various studies have shown the importance of this cultivation as providing a place for the foraging, rest and reproduction of aquatic and granivorous birds (Fazola; Ruiz, 1996; Elphick, 2010; Sandilyan et al., 2010). This study presents previously unpublished information from Santa Catarina about monthly abundance, diversity and evenness of granivorous birds in three areas of irrigated rice plantation in Itajaí, Santa Catarina, as well as on the potential impact of Sicalis flaveola and Sturnella superciliaris in these paddies.

A total of about 149,000 ha of irrigated rice are cultivated in the region of the Itajai Valley on the northern part of the Santa Catarina State coast, with the sowing of previously germinated seeds in water depth (EPAGRI, 2009). The cultivation cycle may be divided into the vegetative, reproductive and maturation phases, determined by the size of the panicle. The vegetative phase lasts from the sowing to the first differentiation of the panicle at $30 \mathrm{~cm}$. In the reproductive phase, the rice reaches a height of $70 \mathrm{~cm}$, with the formation of the panicle and the later flowering. In the maturation phase, the panicle attains about $90 \mathrm{~cm}$ and the grains are ready to be harvested (CrozArioL, 2008).

The cultivar most commonly used is "Epagri 109" (Empresa Pesquisa Agropecuária Extensão Rural de Santa Catarina) developed at the Itajaí experimental station and which presents good productivity and grain quality, with a 142-day cycle (VIEIRA et al., 2007). The cultivation of irrigated rice in these regions yields two crops, the main one (Crop I) covering the months of August through February, and the smaller one (Crop II) extending from March to June.

The objective of this work was study the granivorous birds Sicalisflaveola and Sturnella superciliaris and their potential impact on irrigated rice cultivation, Itajaí, Santa Catarina, using the mean abundance of granivorous birds, mean fluctuation of diversity and evenness of granivorous birds in the irrigated rice fields.

\section{MATERIALS AND METHODS}

The granivorous birds were sampled monthly from August 2010 to July 2011, covering an entire annual cycle of the irrigated rice cultivation in 3 areas - I (40 ha), II (30 ha) and III (20 ha) - , equidistant from each other, with a total of 90 ha monitored, chosen by their easy access to Itajaí, Santa Catarina, Brazil (Figure 1).

The birds were counted with the aid of binoculars $(10 \times 50)$ in the period from 7:00 a.m. to 1:00 p.m., sampled during random walks on the dikes, with permanence of 10 minutes at each of several fixed points on them, to cover the whole area. The birds sighted on the rice fields, and those perching on the surrounding vegetation were registered. They were identified by means of guides (Rosário, 1996; ENDrigo; Develey, 2004; Bini, 2009) and organized in lists in accordance with the classification of the Comitê Brasileiro de Registros Ornitológicos (CBRO, 2014).

During the sampling process of August 2010, 33 Sturnella superciliaris and 23 Sicalisflaveola were found dead, killed by the ingestion of poisonous seeds deposited on the dikes, in area II. The rice grains found in their gastrointestinal tracts were weighed and the average consumption per species calculated.

In this estimate, it was considered that each bird undertook at least two foraging expeditions in the course of the day (morning and afternoon) (SICK, 2001). The average weight of the rice found was multiplied by 10 days (period of sowing), as well as by the number of birds of these species registered in each area. The same procedure was adopted for the maturation phase (Crop I) and Crop II by 30 days (from the formation of the panicle until the harvest). The potential impact of the two granivorous species on the cultivation of irrigated rice was estimated by means of these calculations.

The species counted were grouped in accordance with occurrence as regular ( 9 to 12 months), seasonal (6 to 8 consecutive months) or occasional (1 to 5 months) (BRANCO et al., 2011). Shannon's diversity and Pielou's evenness indices were calculated on the basis of the abundance values registered for the months concerned (LudwiG; ReYNOLDs, 1988).

ANOVA was used to compare the abundance of the granivorous birds, as well as of Sicalis flaveola and Sturnella superciliaris, as between the areas, and, whenever significant differences occurred, the Tuckey-Kramer test was applied to indicate which averages were distinct (ZAR, 1999). 


\section{RESULTS}

During the study period, it was registered the occurrence of 10,083 contacts of birds belonging to 2 orders, 5 families and 10 species, 9 of them being common to the 3 areas (Table 1). The regular species contributed with $45.17 \%$ of the sightings, followed by the occasional (30.37\%) and seasonal (24.43\%), of which Sturnella superciliaris (43.88\%) and Sicalis flaveola (36.88\%) participated with the greatest abundances (Table 1).

The abundance of the granivorous birds oscillated over the year with no significant differences between the months sampled in areas I $\left(\mathrm{F}_{11-96}=0.4156 ; \mathrm{p}<0.05\right)$, II $\left(\mathrm{F}_{11-108}=1.3570\right.$; $\mathrm{p}<0.05)$ and III $\left(\mathrm{F}_{11-108}=1.1320 ; \mathrm{p}<0.05\right)$, the largest contingents occurred after the sowing and germination of the seed (October) and of the harvesting of Crops I (March) and II (July) (Figure 2), whereas the oscillations of October-February and April-June were related to the maturation of the rice and the offer of grasses on the dikes, contributing to random occupation.

The diversity and evenness indices presented the same tendency to vary, with average values oscillating between $0.47 \pm 1.37$ and $0.29 \pm 0.83$, respectively (Figure 3).
$\mathrm{N}$

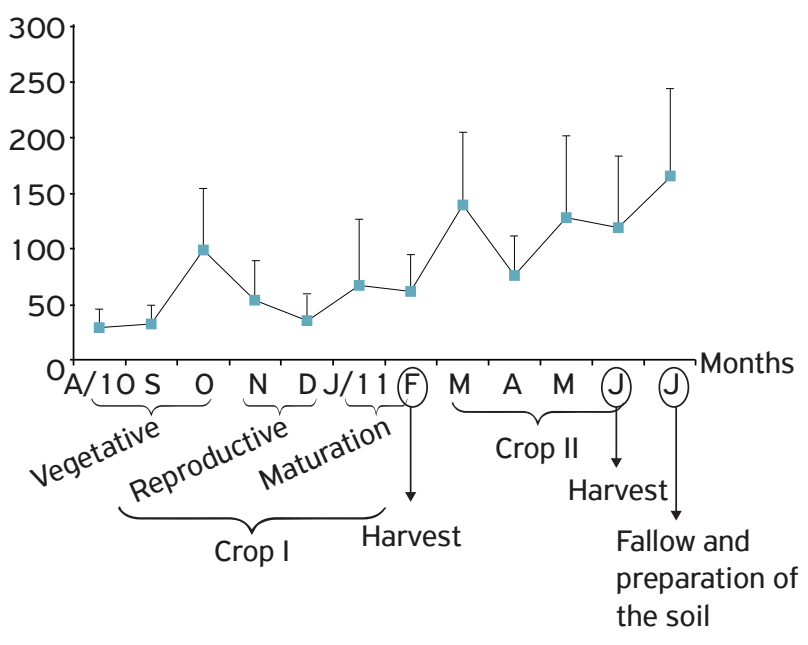

A: August; S: September; O: October; N: November; D: December; J: January; F: February; M: March; A; April; M: May; J: June; J: July.

Figure 2. Monthly (August to July) mean abundance of granivorous birds in the irrigated rice fields, Itajaí, Santa Catarina. The estimated loss of rice due to the joint action of S. superciliaris and S. flaveola.

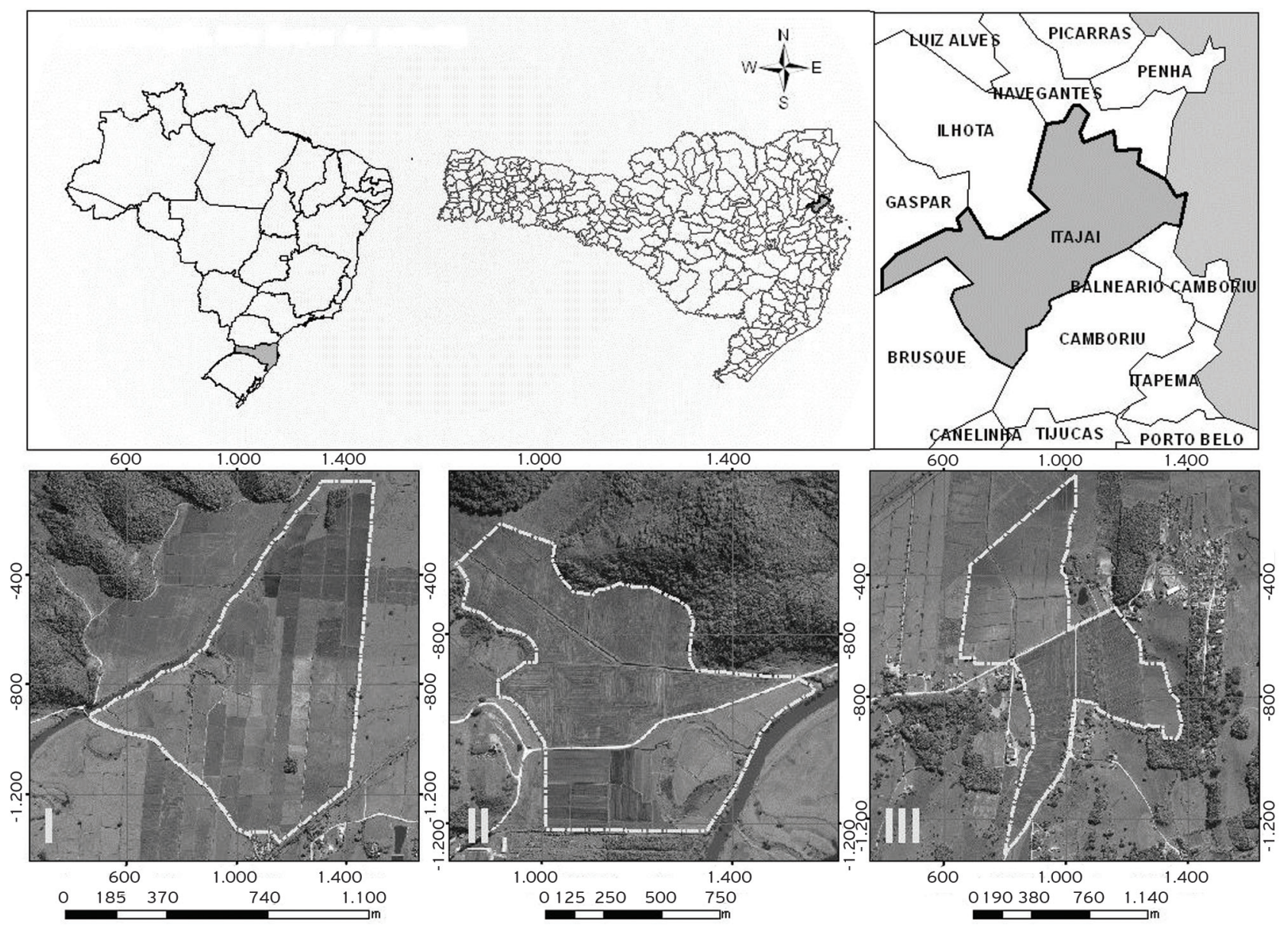

Figure 1. Location of study areas, a total of 90 hectares monitored, chosen by virtue of their ease of access in, Itajaí, Santa Catarina, Brazil. 
A gradual fall occurred as from August, reaching the lowest values in January, followed by an increase and oscillations until July.

Of the 10 species of granivorous bird monitored, the White-browed blackbird Sturnella superciliaris and the Safron finch Sicalis flaveola contributed with $80.76 \%$ of the total abundance, thus influencing the sampling directly (Figure 4); however, these species together presented similar fluctuations over the year in the cultivated areas $\left(\mathrm{F}_{2-33}=0.2952\right.$; $\mathrm{p}<0.05$ and $\left.\mathrm{F}_{2-33}=0.9854 ; \mathrm{p}<0.05\right)$ respectively, with the highest values occurring during the autumn months and the lowest in the spring.

However, when tested separately, the abundances of Sicalis flaveola were significantly different from month to month $\left(\mathrm{F}_{11-33}=7.1290 ; \mathrm{p}<0.01\right)$, influenced in great part by the lower values registered in December and January (Figure 4).

During the analysis of the stomachs of Sturnella superciliaris and Sicalis flaveola, only grains of rice were found. The average number of grains was 14.33 for Sturnella superciliaris and 12 for Sicalis flaveola, equivalent to 0.46 and $0.38 \mathrm{~g}$, respectively, for each species. The estimated loss of rice due to the joint action of

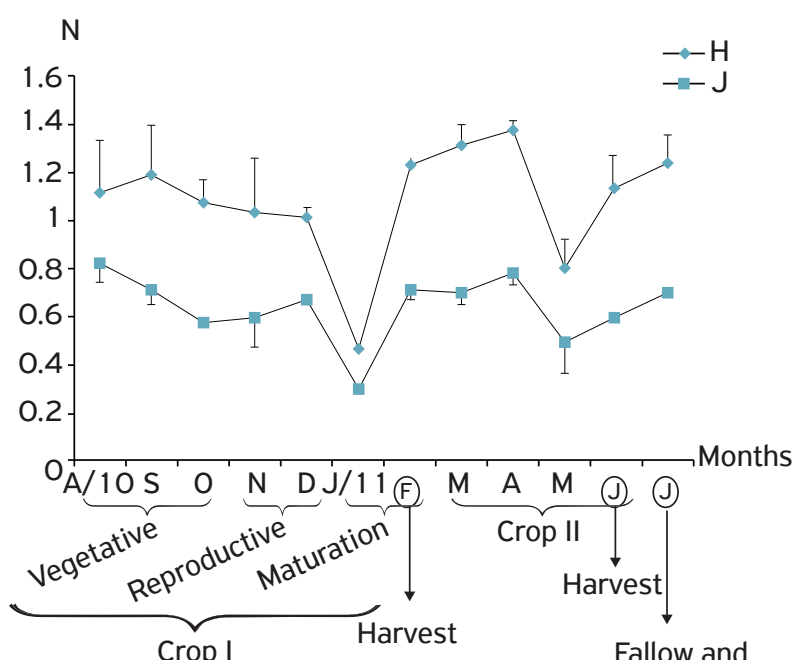

Fallow and preparation of the soil

A: August; S: September; O: October; N: November; D: December; J: January; F: February; M: March; A; April; M: May; J: June; J: July.

Figure 3. Monthly (August to July) mean fluctuation of diversity $\left(H^{\prime}\right)$ and evenness $(J)$ of granivorous birds in the irrigated rice fields.

Table 1. Avifauna found in ricefields by percentage and occurrence.

\begin{tabular}{|c|c|c|c|c|c|c|c|c|c|}
\hline \multirow{3}{*}{ Order/Family/Species } & \multicolumn{9}{|c|}{ Areas } \\
\hline & \multicolumn{3}{|c|}{ I } & \multicolumn{3}{|c|}{ II } & \multicolumn{3}{|c|}{ III } \\
\hline & $\mathbf{n}$ & $\%$ & Oc & $\mathbf{n}$ & $\%$ & Oc & $\mathbf{n}$ & $\%$ & $\mathrm{Oc}$ \\
\hline \multicolumn{10}{|l|}{ Order Columbiformes } \\
\hline \multicolumn{10}{|l|}{ Family Columbidae } \\
\hline Columbina talpacoti & 90 & 2.61 & $\mathrm{R}$ & 231 & 7.14 & $\mathrm{R}$ & 165 & 4.84 & 0 \\
\hline Columbina picui & - & - & - & 10 & 0.30 & 0 & 31 & 0.91 & 0 \\
\hline Patagioenas picazuro & 23 & 0.67 & $\mathrm{~S}$ & 63 & 1.95 & $\mathrm{~S}$ & 42 & 1.23 & 0 \\
\hline \multicolumn{10}{|l|}{ Order Passeriformes } \\
\hline \multicolumn{10}{|l|}{ Family Emberezidae } \\
\hline Zonotrichia campensis & 24 & 0.70 & 0 & 38 & 1.15 & $\mathrm{R}$ & 20 & 0.59 & $\mathrm{~S}$ \\
\hline Sicalis flaveola & 1,115 & 32.36 & $\mathrm{R}$ & 1,136 & 35.26 & $\mathrm{R}$ & 1,468 & 43.03 & $\mathrm{R}$ \\
\hline Volatinia jacarina & 173 & 5.02 & $\mathrm{R}$ & 146 & 4.50 & $\mathrm{R}$ & 133 & 3.90 & $\mathrm{R}$ \\
\hline \multicolumn{10}{|l|}{ Family Icteridae } \\
\hline Molothrus bonariensis & 13 & 0.38 & 0 & 77 & 2.38 & 0 & 1 & 0.03 & 0 \\
\hline Sturnella superciliaris & 1,836 & 53.29 & $\mathrm{R}$ & 1,237 & 38.39 & $\mathrm{R}$ & 1,363 & 39.96 & $\mathrm{R}$ \\
\hline \multicolumn{10}{|l|}{ Family Estrildidae } \\
\hline Estrilda astrild & 148 & 4.30 & $\mathrm{R}$ & 283 & 8.75 & $\mathrm{~S}$ & 100 & 2.93 & $\mathrm{~S}$ \\
\hline \multicolumn{10}{|l|}{ Family passeridae } \\
\hline Passer domesticus & 23 & 0.67 & 0 & 6 & 0.18 & 0 & 88 & 2.58 & 0 \\
\hline Total & 3,445 & 100 & & 3,227 & 100 & & 3,411 & 100 & \\
\hline
\end{tabular}

Oc: Occurrence; R: Regular; S: Seasonal; O: Occasional. 
Sturnella superciliaris and Sicalis flaveola was, on average, lower during crop I (33.9 kg) than during crop II (49 kg), varying considerably as between the cultivated areas, with an average loss per area of between $8.35 \pm 1.66$ and $6.10 \pm 1.48 \mathrm{~kg}$ of rice, respectively, for these two species (Table 2 and 3), giving a total average annual loss of $82.9 \mathrm{~kg}$ for the 90 ha of rice monitored.

According to Ministério da Agricultura (2011), the average annual price of a $50 \mathrm{~kg}$ sack of irrigated rice in 2011 was $\mathrm{R} \$ 29.60$. Taking $82.9 \mathrm{~kg}$ as the amount of rice consumed by the two species, by rule of three, it was estimated that the total loss caused was of $\mathrm{R} \$ 49.07$ in the three areas.

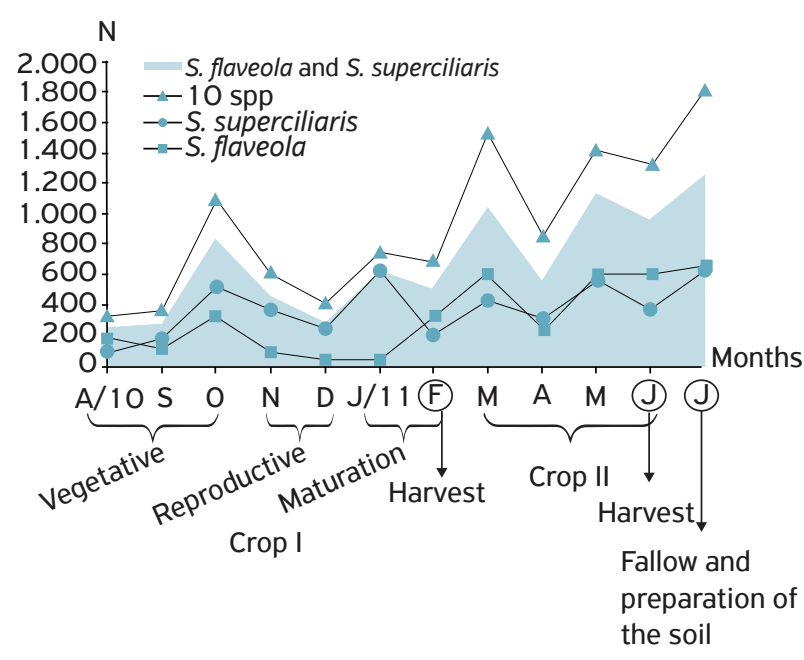

A: August; S: September; O: October; N: November; D: December; J: January; F: February; M: March; A; April; M: May; J: June; J: July.

Figure 4. Annual (August to July) abundance of S. superciliaris and S. flaveola in relation of the other species of granivorous birds.

\section{DISCUSSION}

The assemblage of granivorous birds in the areas of irrigated rice is composed of species known to be common to the cereal plantations of Santa Catarina (Rosário, 1996) and which use the region preferentially for feeding and resting (FAzolA; Ruiz, 1996; Dias; Burguer, 2005).

The composition of the assemblage of granivorous birds in the plantations of irrigated rice in the South-Southeast region is dominated by a few species, generally exclusive to the region: in the Paraíba Valley by Chrysomus ruficapillus (73.6\%) and Sturnella superciliaris (27.4\%) (Crozariol, 2008); in Rio Grande do Sul, there are an additional of 5 species, being noteworthy among them Agelaius ruficapillus (65\%), Sicalis luteola (35\%) and Sturnella superciliaris (24\%) (DiAs; BuRguer, 2005), attaining a total of 10 in the region of Itajaí, Santa Catarina, dominated by Sturnella superciliaris and Sicalis flaveola, which together contributed with $80.6 \%$ of the abundance.

The ample distribution of some granivorous species found in irrigated rice plantations may be common to other regions due to the expansion of agriculture and the diversification of grain crops. In sorghum plantations in Minas Gerais, 16 species of bird were found (JACINTO et al., 2007), Aratinga leucophtalma, Patogienas picazuro, Volatina jacarina and Gnorimopsar chopi being considered those responsible for the greatest damage to the plantations when they feed on the bunches of sorghum. Of these, only Patogienas picazuro and Volatina jacarina were common to the irrigated rice plantations of Itajaí, though not causing any considerable damage to the rice plantations in view of the abundance of Sturnella superciliaris and Sicalis flaveola.

Table 2. Estimated loss of rice by the action of Sturnella superciliaris in the areas sampled.

\begin{tabular}{|c|c|c|c|c|c|c|c|c|}
\hline \multirow{3}{*}{ S. superciliaris } & \multicolumn{4}{|c|}{ Crop I } & \multirow{3}{*}{ Loss (R\$) } & & & \multirow{3}{*}{ Loss (R\$) } \\
\hline & \multicolumn{2}{|c|}{ Aug - Sep 2010} & \multicolumn{2}{|c|}{ Jan - Feb 2011} & & \multicolumn{2}{|c|}{ May - Jun 2011} & \\
\hline & $\mathbf{n}$ & kg & $\mathbf{n}$ & kg & & $\mathbf{n}$ & kg & \\
\hline Area I (40 ha) & 86 & 0.8 & 407 & 11.2 & 7.10 & 513 & 14.1 & 8.35 \\
\hline Area II (30 ha) & 43 & 0.4 & 201 & 5.5 & 3.49 & 304 & 8.4 & 4.97 \\
\hline Area III (20 ha) & 122 & 1.1 & 101 & 5.2 & 3.73 & 101 & 2.8 & 1.66 \\
\hline Total (90 ha) & 251 & 2.3 & 709 & 21.9 & 14.32 & 918 & 25.3 & 14.98 \\
\hline
\end{tabular}

Table 3. Estimated loss of rice by the action of Sicalis flaveola in the areas sampled.

\begin{tabular}{|c|c|c|c|c|c|c|c|c|}
\hline \multirow{3}{*}{ S. flaveola } & \multicolumn{4}{|c|}{ Crop I } & \multirow{3}{*}{ Loss (R\$) } & \multirow{2}{*}{\multicolumn{2}{|c|}{$\begin{array}{c}\text { Crop II } \\
\text { May - Jun } 2011\end{array}$}} & \multirow{3}{*}{ Loss (R\$ } \\
\hline & \multicolumn{2}{|c|}{ Aug - Sep 2010} & \multicolumn{2}{|c|}{ Jan - Feb 2011} & & & & \\
\hline & $\mathrm{n}$ & $\mathrm{kg}$ & $\mathrm{n}$ & $\mathrm{kg}$ & & $\mathrm{n}$ & $\mathrm{kg}$ & \\
\hline Area I (40 ha) & 80 & 0.6 & 163 & 3.7 & 2.54 & 254 & 5.8 & 3.43 \\
\hline Area II (30 ha) & 77 & 0.6 & 83 & 1.9 & 1.48 & 333 & 7.6 & 4.50 \\
\hline Area III (20 ha) & 97 & 0.7 & 95 & 2.2 & 1.72 & 450 & 10.3 & 6.10 \\
\hline Total (90 ha) & 254 & 1.9 & 341 & 7.8 & 5.74 & 1,037 & 27.7 & 14.03 \\
\hline
\end{tabular}


The fragmentation of the vegetation coverage by agricultural activity can greatly alter the composition of the fauna, and this alteration is most evident as it affects birds (Anjos, 1998). With the expansion of the cultivation of irrigated rice using pre-germinated seed, a new feeding resource has become available to birds (DiAs; BURGUER, 2005), which may directly benefit the local granivorous species. This resource, however, had been little exploited by this guild of birds in the plantations monitored in this project due to their not foraging in water (Dias; Burguer, 2005), reflected in their low abundance during the period of sowing. However, the oscillations in the reproductive phase of Crops I and II were probably occasioned by the presence of seed-producing grasses on the dikes and in the surrounding vegetation.

Generally speaking, the greatest abundances at the end of the harvests are determined by the availability of grain during the harvesting process, occasioned by the presence of juveniles (DiAs; Burguer, 2005), showing that the cultivated areas are used during the post-reproductive dispersal, especially by Sturnella superciliaris and Sicalis flaveola.

The irrigated paddy-fields, in their role as feeding places, may harm birds by virtue of the toxicity of the agricultural pesticides used in them (Barbieri; Ferreira, 2011), which, after the prohibition of organochlorides (DDT) in 1985, came to include the now widely-used carbonates and organophosphates (VAldes, 2010). In this present study, 56 birds were found dead, possibly poisoned deliberately while they were foraging on the rice grains soaked in the carbofuran deposited on the dikes surrounding the plantations.

The two most-affected species, Sturnella superciliaris $(\mathrm{n}=33)$ and Sicalis flaveola $(\mathrm{n}=23)$, are considered to be pests by the local farmers as, supposedly, they harm the crops. However, the total loss in the 3 areas monitored was of only $82.9 \mathrm{~kg}$, equivalent to $\mathrm{R} \$ 49.07$, and deemed insufficient impact when the loss was calculated during the process of harvesting or as compared with the price of pesticide ( $\mathrm{R} \$ 71.10$ per $10 \mathrm{~kg}$ bag or $\mathrm{R} \$ 60.17$ per liter) (BARBIERI et al., 2016). Camperi et al. (2004), on analyzing the composition of the diet of 34 Sturnella superciliaris, discovered that only $27 \%$ of the food items consisted of seeds and grains, whereas in the gastrointestinal contents of the
Sturnella superciliaris and Sicalis flaveola of Itajaí only grains of rice were found. On the other hand, the $73 \%$ of the items classified as arthropods, the most abundant being insects and arachnids (CAMPERI et al., 2004), demonstrate that Sturnella superciliaris does not act exclusively as a grain-eater in the plantations of Argentina, but may also contribute to insect control.

Thus, the party whose interests are most harmed when they poison the birds are the producers themselves, as they spend more resources and time on it than they would otherwise lose, quite apart from the risk of fines and imprisonment which they run (art. 16 Law no 7,802 - 11/07/89).

Seeds treated with carbofuran, apart from poisoning the birds, can also lead to the death of predators by secondary contamination (Almeida et al., 2010) as was observed in Area II with the snake Liophis miliaris when it consumed dead amphibians and birds. In certain regions of Europe and Canada, the use of this insecticide has contributed to the reduction of various bird species in agricultural areas (Mineau, 2005).

Although there exist various studies which describe the mortality of birds due to the use of insecticides of the carbarnate and organophosphate group (Agriculture Canada, 1993, Mineau et al., 1999, Mineau, 2005, Almeida et al., 2010), in Brazil there is still little information available on the impact of this group of insecticides on the bird fauna of the plantations of irrigated rice. An increased awareness on the part of producers, with an allied intensification of inspections, is of fundamental importance in the conservation of biodiversity.

\section{ACKNOWLEDGEMENTS}

Joaquim Olinto Branco and Edison Barbieri wish to thank the $\mathrm{CNPq}$ for the grant given for productivity in research. They also wish to thank the persons who contributed in various ways during the fieldwork, Ana Paula Abreu and, especially, Dra. Maria José Lunardon Branco and Dr. Joaquim Olinto Branco for the learning and dedication, as also the paddy workers, Edésio, Pedro Paulo and especially João for their help and the valuable information shared.

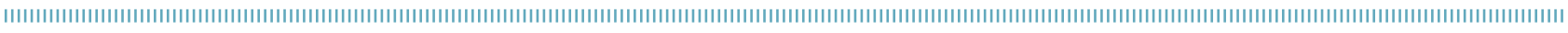
REFERENCES

AGRICULTURE CANADA. Special review of carbofuran inseticide: Effects on avian fauna and value to agriculture. Plant Industry Directorate, Ottawa, Canada. 1993.

ALMEIDA, A.; COUTO, H.T.; ALEMIDA, A.F. Camouflaging of seeds treated with pesticides mitigates the mortality of wild birds in wheat and rice crops. Scientia Agricola, v. 67, p. 176-182, 2010.
ANJOS, L. Consequências biológicas da fragmentação no norte do Paraná. Série Técnica IPEF, v.12, p. 8-94, 1998.

BARBIERI, E.; MOREIRA, P.; LUCHINI, L.A.; HIDALGO, K.R.; MUNOZ, A. Assessment of acute toxicity of carbofuran in Macrobrachium olfersii (Wiegmann, 1836) at different temperature levels. Toxicology and Industrial Health, v.32, n.1, p.7-14, 2016. 
BARBIERI, E.; FERREIRA, L.A.A. Effects of the organophosphate pesticide Folidol $600(\mathrm{R})$ on the freshwater fish, Nile Tilapia (Oreochromis niloticus). Pesticide Biochemistry and Physiology, v.99, n.3, p.209-214, 2011.

BINI, E. Aves do Brasil: Guia prático. Lages: Homem-pássaro publicações, 2009. 233p.

BRANCO, J.O.; FREITAS JUNIOR, F.; FRACASSO, H.A.A.; BARBIERI, E. Biodiversidade no estuário do Saco da Fazenda, Itajaí, SC. O Mundo da Saúde, v.35, p.12-22, 2011.

CAMPERI, A.R.; FERRETTI, V.; CICCHINO, A.C.; SOAVE, G.E. Diet composition of the white-browed blackbird (Sturnella superciliaris) at Buenos Aires province, Argentina. Ornitología Neotropical, v.15, p.299-306. 2004

COMITÊ BRASILEIRO DE REGISTROS ORNITOLÓGICOS (CBRO). Lista das aves do Brasil. 2014. Disponível em: <http://www.cbro. org.br>. Acesso em: 15 abr. 2011.

COMPANHIA NACIONAL DE ABASTECIMENTO (CONAB). Levantamento de grãos 2010/2011. Disponível em: <http:// www.conab.gov.br>. Acesso em: 27 set. 2011.

CROZARIOL, M.A. Aves associadas às diferentes fases do crescimento do arroz irrigado no sudeste do Brasil. Buenos Aires: Wetlands International, Primer taller para la Conservación de Aves Playeras Migratorias en Arroceras del Cono Sur. 2008. 123p.

DIAS, R.A.; BURGUER, M.I. A assembléia de aves de áreas úmidas em dois sistemas de cultivo de arroz irrigado no extremo sul do Brasil. Revista Brasileira de Zoologia, v.13, p.63-80, 2005.

ELPHICK, C.S. Why study birds in rice fields? Waterbirds, v.33, n. 1, p.1-7, 2010.

ENDRIGO, E.; DEVELEY, P.F. Guia de campo: As aves da grande São Paulo. São Paulo: Aves e Fotos. 2004

EPAGRI. Histórico da produção de arroz irrigado. Florianópolis. 2009. Disponível em: <www.epagri.sc.gov.br>. Acesso em: 13 set. 2010.

EPAGRI. Mercado Agrícola. 2011 . Disponível em: <www.epagri. sc.gov.br>. Acesso em: 27 set. 2011.

FAO - Food and Agriculture Organization. 2010. Arroz híbrido para contribuir a la seguridad alimentaria. Disponível em: http:// www.fao.org/home/en/. Acesso em: jan. 2011.

FAZOLA, M.; RUIZ, X. The value of rice fields as substitutes for natural wetlands for waterbirds in the Mediterranean Region. Colonial Waterbirds. Special publication, v.19, n.1, p.122-128, 1996. Special publication 1.
INSTITUTO DE ECONOMIA AGRÍCOLA. Defensivos Agrícolas, informe 2011 . Disponível em: <http://www.iea.sp.gov.br/out/ precos/aenda0405.php>. Acesso em: 13 dez. 2011.

JACINTO, J.C.; TOTI, T.P.; GUARITÁ, R.L.; MELO, C. Dano em um cultivo de sorgo (Sorghum bicolor) causado por aves. In: VIII CONGRESSO DE ECOLOGIA DO BRASIL, 2007, Caxambu. Anais.. Caxambu: MG. p.54-48. 2007

LUDWIG, J.A.; REYNOLDS, J.F. Statistical ecology: a primer on methods and computing. New York: John Wiley \& Sons, 1998. 245p.

MINEAU, P.; FLETCHER, M.R.; GLASER, L.C.; THOMAS, N.J.; BRASSARD, C.; WILSON, L.K.; ELLIOTT, J.E.; LYON, L.; HENNY, C.J.; BOLLINGER, T.; PORTER, S.L. Poisoning of raptors with organophosphorus and carbamate pesticides with emphasis on Canada, US, and U.K. Journal of Raptor Research, v.33, p.1-37, 1999.

MINEAU, P. Direct losses of birds to pesticides: beginnings of a quantification. USDA, Washington, D.C., USA. Forest Service General Technical Report PSW-GTR-191, v.2, p.1065-1070, 2005.

MINISTÉRIO DA AGRICULTURA. Arroz. 2010. Disponível em: <www.agricultura.gov.br>. Acesso em: 13 abr. 2011.

PARSONS, K.C.; MINEAU, P.; RENFREW, R.B. Effects of pesticide use in rice fields on birds. Waterbirds, v.33, n. 1, p.193-218, 2010.

ROSÁRIO, L.A. As aves em Santa Catarina: Distribuição geográfica e meio ambiente. Florianópolis: FATMA, 1996.

SICK, H. Ornitologia Brasileira. 5. ed. Rio de Janeiro: Nova Fronteira, 2001. $901 \mathrm{p}$.

SANDILYAN, S.; THIYAGESAN, K.; NAGARAJAN, R. Do agriculture lands serve as alternative habitat for shorebirds? A systematic survey is the need of this hour in India Materials and Methods. Wader Study Group Bulletin, v. 117 , n.3, p.194-195, 2010.

VALDES, S.A.C. Avaliação da exposição a agrotóxicos em aves silvestres de vida livre. In: MATTER, S.V.; STRAUBE, F.C.; ACCORDI, I.A.; PIACENTINI, V.Q.; CÂNDIDO Jr., J.F. (eds) Ornitologia e Conservação: Ciência aplicada, Técnicas de pesquisa e Levantamento. Rio de Janeiro: Tecnicals Books, 2010 , p.429-439.

VIEIRA, J.; MARSCHALEK, R.; SCHIOCCHET, M.A. Cultivares de arroz da Epagri - Descrição e caracterização. Florianópolis: Epagri. (Epagri. Boletim Técnico, 138), 2007. 125p.

ZAR, J.H. Biostatistical Analysis. 4 ed. New Jersey: Prentice-Hall, 1999. $810 p$. 